\title{
Established and Alternative Literary Criticism: A Study of Marguerite Duras's Works Reviewed in Sweden
}

Mattias Aronsson

Dalarna University

\section{Introduction}

This chapter examines two types of reviews issued in Sweden of Marguerite Duras's works translated into Swedish. A corpus of texts published in the Swedish press has been collected (here called "established criticism"), and this material is contrasted with reviews uploaded in the blogosphere by "prosumers" (in the study labelled "alternative criticism"). ${ }^{\mathrm{I}}$ Hence, the two types of literary criticism are published in separate arenas, and we may assume that they target different audiences and serve different purposes. The reviews are also written by individuals occupying very different positions in the world of literature. The established critics publish their reviews in distinguished or at least wellknown newspapers and magazines. These individuals have thus attained dominating positions in the field of cultural production. Most of the bloggers that are present in the corpus, on the other hand, must be considered as non-established in the cultural arena - since they do not have access to these renowned publications. Instead, they have positioned themselves in the alternative arena

I The first results have been published in a previous article (Aronsson, 20I6), and the present study constitutes the second part of the research project.

How to cite this book chapter:

Aronsson, M. 2021. Established and Alternative Literary Criticism: A Study of Marguerite Duras's Works Reviewed in Sweden. In: Jonsson, H., Berg, L., Edfeldt, C. and Jansson, B. G. (eds.) Narratives Crossing Borders: The Dynamics of Cultural Interaction. Pp. 307-335. Stockholm: Stockholm University Press. DOI: https://doi.org/Io.I6993/bbj.n. License: CC-BY 4.० 
of the blogosphere, and they have embraced the "do-it-yourself" attitude of the Internet. Even if we regard the alternative online criticism as being a part of the public discourse today, we should remain aware that it has not attained, and will probably never attain, the same status as established criticism. To give an obvious example, a review published in a highbrow daily newspaper, such as The Times in Britain, The New York Times in the United States, or Svenska Dagbladet in Sweden, will always provide the literary author, and the reviewer, with more cultural capital than a text published on a personal blog. Therefore, I will, in this study, consider the established criticism as a dominating discourse, and the criticism published in the blogosphere as an alternative discourse.

The study investigates the discourses of these two types of literary criticism, with a special focus on the question: What are the main characteristics of the dominating discourse of the established criticism, and what are the main characteristics of the alternative discourse in the blogosphere? A corpus of Swedish reviews of Duras's oeuvre has been chosen because many of her works have recently been published in Swedish translation. However, no reader-response study based on this material has ever been issued.

The alternative literary criticism published on the Internet represents a somewhat new phenomenon, insomuch as it constitutes a parallel to the traditional reviews published in the "old" press - such as printed daily newspapers and literary magazines. It also presents the interpretations and opinions of "ordinary" readers, and by that I refer to people who do not occupy a position of power in the field of cultural production. This category of reader did not have the opportunity to participate actively in the literary debate prior to the democratization of information and communication technology - i.e., before personal computers with highperforming Internet connection, smartphones, IPads, etc. became an everyday household item for most people. In that respect, reviews written and published by bloggers on the Internet represent a relatively new facet of literary criticism.

The corpus for this research project has been collected using the search engine Google. Originally, 20 reviews labelled established criticism and published in the Swedish press were collected - as were 20 reviews published in the blogosphere and labelled alternative criticism. The material was collected in March 2016. 
The established criticism appeared in daily national newspapers (Svenska Dagbladet, Dagens Nyheter, Expressen), in regional papers (Göteborgs-Posten, Upsala Nya Tidning, Sydsvenskan) or in periodicals (Fokus). Some texts were found in cultural magazines published exclusively on the Internet (Dixikon, Litteraturmagazinet, Tidningen Kulturen). The alternative criticism was collected from the blogosphere and, in two cases, from customers' reviews on a web-based bookseller's site (Bokus). Hence, the corpus comprised 40 texts altogether. For the discourse analysis presented in this part of the research project, a smaller number of representative reviews ( 6 from the Swedish press and 6 from the blogosphere) have been excerpted in order to illustrate the distinguishing features of established and alternative criticism, respectively. ${ }^{2}$

In the theoretical background below, some aspects of readerresponse studies and the Internet will be presented. I will then briefly discuss some key concepts from the field of discourse analysis that are pertinent for this study.

\section{Theoretical Background}

Recent studies demonstrate the importance of opinions expressed by bloggers in the modern economy, where the "e-commerce" phenomenon has been soaring for quite some years. ${ }^{3}$ Hence,

2 The reviews published in the Swedish press and representing the established criticism are written by Sem-Sandberg (2007), Törnvall (2007), Beckman (20I2), Kåreland (20I4), Van Reis (20I4) and Högström (2015). The reviews published in the blogosphere and representing the alternative literary criticism are composed by Eli (2OI4), Flynner (20I4), Lager (2OI4), Linnea (2OI4), Nilsson (2OI 5 ) and Wiström (2OI 5 ).

3 See, for instance, Ardelet and Brial (20I I, pp. 45-69) and Ritzer, Dean and Jurgenson (2012, p. 386) who argue that "those who prosume on the Internet, especially Web 2.0, are very attractive to capitalists”. Web 2.0 is a term that is sometimes used to describe the "new" version of the Internet, where content is commonly generated by the users themselves. Ritzer, Dean and Jurgenson (ibid., p. 385) explain: "Prosumption on the Internet has increasingly occurred through user-generated content on what has become known as Web 2.0 (in Web I.o, such as AOL or Yahoo, content is generated by the producer, leaving little room for prosumption). Web 2.0 includes the social web with sites such as Flickr and You 
publishing houses must today not only keep an eye on what the established critics in the old media have to say about their publications, but they must also be increasingly aware of the opinions expressed by literary commentators in the blogosphere.

The study is inspired by concepts such as convergence culture and participatory culture, popularized by media researcher Henry Jenkins, as well as other scholars. See, for instance, Jenkins (2006) and Jenkins, Ito and Boyd (20I 5 ). In a culture where old and new media tend to converge, the consumer of literature (as well as other products) has the opportunity to be an active participant in the construction of meaning and value - in this case by writing and uploading book reviews on a personal blog, for instance, or by publishing fanfiction stories in a web-based community. ${ }^{4}$ The notion of prosumer (a neologism created by merging "producer" with "consumer") will be used with reference to this somewhat new actor in the world of commerce - and, indeed, in the world of literary reader-response research.

The Swedish researcher Ann Steiner (20I 2, p. 6I), specialist in the sociology of literature, argues that the non-established critics specifically have become important agents in the modern literary market. ${ }^{5}$ They do not only consume cultural products, but they also contribute to the production of meaning and value by uploading their reviews on the Internet. They have, thus, become prosumers, i.e., agents who combine the role of the producer with that of the consumer. In doing so, they challenge the traditional cultural hierarchies, according to Steiner.

In a previous article presenting the first part of the research project focusing on the Swedish reception of Marguerite Duras's oeuvre, I showed that the alternative criticism published on the

Tube, and much else where users not only consume but also produce content."

4 Jenkins (2006, p. 33I) defines participatory culture in the following way: "Culture in which fans and other consumers are invited to actively participate in the creation and circulation of new content".

5 Steiner (20I2, pp. 5I-63) uses the terms “amatörer" (amateurs) and "amatörrecensenter" (amateur reviewers) when describing critics who publish their texts in the blogosphere, whereas I have chosen to label them alternative or non-established literary critics. 
Internet is largely dominated by women bloggers. ${ }^{6}$ They publish very succinct reviews that are significantly shorter than the texts that make up the established criticism. ${ }^{7}$ The specific books discussed by the bloggers also differ from the ones examined by the established critics. The alternative critics, or "prosumers", review the Durassian classics (e.g., The Lover and The Sea Wall) more often than recently published titles. These bloggers write overtly subjective reviews, using a personal or even intimate tone - as indicated by the high frequency of pronouns in the first person (i.e., the Swedish equivalents to "I", "me", "myself", "my", and "mine") referring to the reviewer herself (or himself). ${ }^{8}$ However, as noted in the previous study (Aronsson, 2016, pp. I 5 and 20), an analysis of quantitative data of first-person pronouns may give certain indications, but it should also be supplemented with a qualitative approach. I will therefore, in this chapter, proceed with a more thorough analysis of the discourses employed in the established and alternative criticism that make up the corpus.

As Schiffrin, Tannen and Hamilton (200I, p. I) point out, there exist numerous definitions of discourse and discourse analysis, emanating from disciplines as diverse as linguistics, anthropology, philosophy and psychology. Quite obviously, literary studies may also be added to the list.

One definition, focusing explicitly on critical discourse analysis, is formulated by Ruth Wodak and reads as follows:

Critical Discourse Analysis sees discourse - the use of language in speech and writing - as a form of "social practice". Describing discourse as social practice implies a dialectical relationship between

${ }^{6}$ The results showed that $80 \%$ of the bloggers ( 16 individuals of 20 ) presented themselves with female names, I0\% (2 of 20) with male names, and for the last I०\% ( 2 individuals), the sex could not be established (Aronsson, 2016, p. 8).

7 When comparing the two types of texts, I found out that the median $\left(=2^{\text {nd }}\right.$ quartile) is 1753 characters (with spaces) for the non-established reviews, compared to 4666 characters for the established criticism (Aronsson, 20I6, p. I2).

8 The frequency of these pronouns was approximately nine times higher than in the established criticism: 295 pronouns per I00 000 characters in the blogosphere compared to 33 pronouns per I00 000 characters in the press (Aronsson, 20I6, p. I4). This is, indeed, a significant difference. 
a particular discursive event and the situation, institution and social structure that frame it: the discursive event is shaped by them, but it also shapes them. That is, discourse is socially constituted, as well as socially conditioned - it constitutes situations, objects of knowledge, and the social identities of and relationships between people and groups of people (Wodak, I997, p. 6).

As I find Wodak's definition informative and useful, I will apply it in this study together with Van Dijk's observations. Van Dijk (200I, p. 352) has pointed out that critical discourse analysis often tends to focus on power relations and the way in which social dominance and inequality are created and reproduced in language. It is therefore akin to disciplines such as gender studies, postcolonial studies and cultural studies. Van Dijk (ibid., p. 355 ) also argues that "access to or control over public discourse and communication is an important 'symbolic' resource" that makes up the power base of a group or institution. "In many situations", Van Dijk (ibid., pp. 355-356) writes, "ordinary people are more or less passive targets of text or talk", whereas members of powerful groups (the elite) "have more or less exclusive access to, and control over, one or more types of public discourse".

Regarding literary criticism, this simple dichotomy of access and control versus non-access and non-control was undoubtedly true in pre-Internet days, when ordinary readers were de facto locked out of the literary debate. That, however, is not necessarily the case anymore, at least not if one includes reviews published in the blogosphere in the definition of "public discourse".

Historically, women have always been a dominated group in patriarchal societies. Sheldon (I997, p. 228) notes that many linguists and literary scholars have denounced the silence regularly imposed on women in many situations. She states that "prescriptions of silence have historically restricted women and girls from expressing their authentic voice in speaking or writing”. A similar opinion is expressed by Reid (20II, p. 7), who argues that women who have ventured into the literary world have long been diminished, contested or quite simply ignored by male competitors already established in the field, who tend to show a "misogynie tenace" (ibid., p. 9), a tenacious misogyny, vis-à-vis women writers and critics. 
So, if women's literary writing and criticism have struggled to find a home and come in from the "wilderness" once identified by Showalter (I98I), then the blogosphere may perhaps provide that safe haven today. After all, according to statistics regarding the situation in Sweden (Findahl, 20I3, p. 35), girls and women make up the vast majority of the readers as well as of the writers of blogs. The women's dominance in literary criticism published on the Internet is also confirmed in my own corpus (Aronsson, 20I6, pp. 7-9).

If the blogosphere is a social medium where different "voices from the margins" - particularly girls and women - have the opportunity to interact with one another without the "prescriptions of silence" identified by Sheldon, then this specific discourse will, indeed, serve as an interesting alternative to the dominating discourse of traditional literary reviews published in the press.

\section{Results}

First, some examples of established criticism published in the press will be presented and discussed, followed by some representative examples of the alternative criticism published in the blogosphere. Finally, the subject of interaction on the Internet will be discussed. The question of interaction is of interest because it introduces a new research field within literary reader-response studies. Traditionally, literary reviews were printed in the paper press, and there was normally no interaction between the reviewer and the readers of the newspaper or the journal, and nor did these readers have access to a convenient arena in which to interact with each other. The Internet, on the other hand, allows for an enormous potential with regards to an open exchange of ideas between the reviewer and the reading public, as well as between individual readers. Therefore, a brief analysis of the interaction in the blogosphere will be included in the study, as this phenomenon is somewhat new to the field of literary reception.

\section{Reviews Published in the Press - An Established Literary Criticism}

The established criticism of Marguerite Duras's work published in the Swedish press is, not surprisingly, often formulated in a 
neutral and impersonal style. In these texts, the reviewer is if not invisible, at least rather inconspicuous. ${ }^{9}$ This is a quality often associated with traditional journalistic prose and presented as the stylistic ideal for this textual genre - especially for cultural journalism (see, for instance, Möijer, I989, pp. 27-28 and Carlsson, 20IO, p. 232). The following quotation, taken from my corpus, gives a representative example of this type of discourse:

There are few authors who can produce such a harsh and unforgiving tone as Marguerite Duras. When she depicts characters who are suffering for one reason or another, it becomes almost unbearable because she does not at any moment show any compassion. This is why they appear to be unusually lonely. In such a way, she stands out in terms of our notions of authors in general and female authors in particular. Marguerite Duras is still a shocking figure (Beckman, 20I2). ${ }^{\text {I० }}$

Notable is how the reviewer, Åsa Beckman, presents an authoritative judgment on Duras's work. In doing so, she provides a classic example of a dominating discourse. Without overtly mentioning that the above verdict expresses her own subjective opinion, the literary critic presents the information as factual and thus indisputable. When she argues that Duras stands out in terms of "our notions of authors in general and female authors in particular" [my translation], it is, obviously, her own idea of authors that is presented as universal. Moreover, the quoted passage consists of a series of declarative sentences. These statements are not incorrect per se, but each and every one of them can, of course, be discussed and problematized - since they are the result of an individual's subjective interpretation of a literary work.

9 As pointed out in the theoretical background, the frequency of first-person pronouns referring to the reviewer himself (or herself) is approximately nine times higher in the bloggers' reviews than in the established criticism.

ro My translation. The original review reads as follows: "Få författare kan skruva till en så hård och obeveklig ton som Marguerite Duras. När hon skildrar personer som av någon anledning lider blir det nästan outhärdligt eftersom hon inte för ett ögonblick visar någon medkänsla. Därför framstår de som ovanligt ensamma. På det sättet bryter hon med vår föreställning om författare $\mathrm{i}$ allmänhet och om kvinnliga författare $\mathrm{i}$ synnerhet. Marguerite Duras är fortfarande en chockerande gestalt" (Beckman, 2012). 
The context of the review is the following: the reviewer, Åa Beckman, is a literary critic who writes for one of Sweden's most distinguished national newspapers (Dagens Nybeter), and the review was published in its section "Culture" - a fact that also contributes to the aura of trustworthiness and authority that surrounds the text. Her father, Erik Beckman, was a well-known writer and literary critic in his time - and her sister, Eva Beckman, was during the period 2010-201 6 head of the cultural department (kulturchef) of Swedish national television. It is thus safe to say that the family name itself conveys an abundance of cultural capital. In fact, one could argue that this example illustrates the point made by Van Dijk above (200I, pp. 355-356), that being that the elite have "exclusive access to, and control over, one or more types of public discourse". In this case, it means that the cultural elite have access to and control over the dominating cultural discourse.

If the objectivity of the review above, upon closer scrutiny, appears to be largely made up of subjective opinions, the next quotation turns out to be even more so. The tone is still very much an authoritative one, illustrated by the fact that the argumentation is made up of declarative sentences, just as we saw in the first example:

It took time for Duras to find her style as an author and her unique way of writing. In the early days of her literary career, she was very insecure and doubted her own ability. But in Moderato cantabile (1958), she shows that she masters her means of expression in a tightly composed story. Le Ravissement de Lol V. Stein (1964) is even more accomplished. Here she portrays a woman on the verge of madness (Kåreland, 20I4). ${ }^{\mathrm{II}}$

The context of the review is as follows: it is written by Lena Kåreland, professor emerita of comparative literature at Uppsala University in Sweden - a detail that, once again, highlights the

II My translation. The original text reads as follows: "Det tog tid innan Duras fann sin stil som författare och sitt speciella sätt att skriva. I början av sitt författarskap var hon mycket osäker och tvivlade på sin förmåga. Men i Moderato cantabile (I958) visar hon att hon behärskar sina uttrycksmedel i en stramt komponerad historia. Än mer fulländad är Le Ravissement de Lol V. Stein (I964) som skildrar en kvinna på gränsen till galenskap" (Kåreland, 20I4). 
importance of cultural capital in the arena of established criticism. It was published in the online literary magazine Dixikon in $2014 \cdot{ }^{\mathrm{I} 2}$

There is no proof presented in the review to support the statement that it took a long time for Marguerite Duras to find her own style and voice in writing - and that she, at the beginning of her literary career, was insecure and doubted her ability as a writer. This thesis is not necessarily incorrect, but the critical and commercial success of Un Barrage contre le Pacifique (The Sea Wall) as early as I950 somewhat contradicts the idea. And since no external source is provided as to the origin of the thesis, an initiated and critical-minded reader is bound to become just a little suspicious. The judgment that Moderato cantabile and Le Ravissement de Lol V. Stein are more accomplished works than the previous publications is, of course, not an indisputable fact either - but merely a subjective opinion. Indeed, on the contrary, one could argue that Duras, in these particular works, changes her style in order to follow the then current trend of the Nouvean Roman - and in doing so, she exposes her insecurity and her lack of independence more than anything else.

Consequently, I see the two quotations above as examples of what Cassirer (2003, p. I 58 ) calls pseudo-objective texts. He argues that a neutral and objective style may very well hide a line of argument that is subjective, biased, and even tendentious. As a matter of fact, upon closer scrutiny the argument in the established reviews of Marguerite Duras's work turns out to be subjective at the very least, despite appearing neutral and trustworthy on the surface - as a mere statement of cold facts.

The authoritative tone of this dominating discourse gives the impression that the reviewers are perfectly in control of the domain they are writing about, and that they have done their homework well. Therefore, it is interesting to note that the examples of established criticism included in my corpus are by no

${ }^{12}$ This periodical started in 2004 and can be seen as an example of the high-quality cultural journals that were born with the Internet. It avoids the costs of printing and distribution that often plague the paper press, but retains the high-brow scope and tone of traditional cultural magazines. Therefore, I include it in the established criticism and regard the review as an example of a dominating discourse. 
means devoid of inaccuracies. There are, in fact, many errors in the reviews published in the Swedish press. Here, I will discuss some examples of the phenomenon:

But "The Sea Wall" has also given rise to one of the most fascinating corrections in the history of literature. In I 986 comes Duras's blockbuster "The Lover", which depicts her relation to the man from Cholen, which is what she calls him here (Beckman, 20I 2). ${ }^{\text {I3 }}$

The text becomes a requiem of repetitions (after an illness, Duras dictated her final books), but the purity and the singular clarity in this book's prose - carefully reproduced by the translator Kennet Klemets - are still recognizable and serve as a way into the earlier literary production that began in 1947 (van Reis, 20I4). ${ }^{14}$

The first reviewer (Åsa Beckman) has the year of publication of Duras's most famous work wrong. In fact, Älskaren (The Lover) did not appear in I986, as is suggested in the text. The novel was originally published in French in 1984, and the Swedish translation dates from I985. The second critic (Mikael van Reis, editor-in-chief of the section on culture (kulturchef) of GöteborgsPosten, the leading regional newspaper in western Sweden), claims that Duras began her career as a writer in I947. The correct year is, in fact, I943. ${ }^{\text {I5 }}$ In 1947, when the first Swedish translation appeared, Duras had already published two novels in France, one by the dominating publishing house Gallimard.

Another case worth mentioning concerns the central character of "M. Jo" in The Sea Wall. Several established critics depict him as a man of Chinese origin, just as the central male protagonist

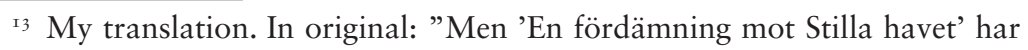
också gett upphov till en av litteraturhistoriens mest fascinerande korrigeringar. I986 kommer Duras storsäljare 'Älskaren' som beskriver hennes relation till mannen från Cholen, som hon här kallar honom” (Beckman, 20I2).

${ }^{\text {I4 }}$ My translation. In original: "Texten blir till en dödsmässa av upprepningar (efter ett sjukfall dikterade Duras sina sista böcker), men renheten och den säregna klarheten i denna boks prosa - som översättaren Kennet Klemets varsamt återger - känns ändå igen och lämnar här en ingång till hela det tidigare författarskapet som tog sin början I947" (van Reis, 20I4).

is That is, if one does not include the very propagandistic and pro-colonial work L'Empire français, which Duras co-wrote with Philippe Roques in I940. This volume is, incidentally, the only book in existence published under the name of Marguerite Donnadieu (Marguerite Duras's real name). 
in The Lover and The North China Lover is a Chinese man. See reviews written by Steve Sem-Sandberg in Svenska Dagbladet (2007), Åsa Beckman in Dagens Nyheter (2012), and Jenny Högström in Sydsvenska Dagbladet (2015). There is, however, no textual support in The Sea Wall backing this thesis, as has been pointed out repeatedly in academic research (see, for instance, Ahlstedt, 2003, p. 78; Pagès-Pindon, 20I 2, p. 74; Aronsson, 20I 3 , p. I88; and Chalonge, 2014, pp. 32-33).

Of course, one may argue that it is somewhat petty to nitpick about erroneous details of minor significance, after all errare bumanum est. But the interesting aspect here, I must stress, is that these inaccuracies are recurrent as well (or especially) in this authoritative and dominating discourse. For my next example, I will return to Lena Kåreland's review quoted above:

Marguerite grew up with two older brothers in a family without social esteem, a family where there was always a money shortage, a family where the father was missing - he died when Marguerite was four years old - and where the mother was mentally unstable (Kåreland, 20I4). ${ }^{16}$

This excerpt is interesting because it puts the spotlight on a general tendency among commentators of Duras's work to confound fiction with reality, and, especially, to take the author's own assertions at face value. One can read in Duras's oeuvre, for instance in Les Lieux de Marguerite Duras (Duras \& Porte, I977, p. 48), that her father died when she was four years old. This is not true, however, as her biographer, Jean Vallier (2010, pp. I6, I93 and 205), has shown. Marguerite was, in fact, aged seven and a half when her father, Henri Donnadieu, passed away in December I921. ${ }^{17}$

The information concerning her mother's mental instability seems to be lifted directly from Duras's literary texts. She has, in fact, written extensively on the subject: in fictionalized form

${ }^{16}$ My translation. The original text reads: "Marguerite växte upp med två äldre bröder i en familj utan socialt anseende, en familj där man alltid hade ont om pengar, en familj, där fadern saknades - han avled när Marguerite var fyra år - och där modern var psykiskt instabil” (Kåreland, 20I4).

${ }^{17}$ This information may also be found elsewhere in academic research - for instance in Bouthors-Paillart (2002, p. 5 ) and Pagès-Pindon (201 2, p. I 5 ). 
in The Sea Wall, in dramatized form and adapted for the theater in L'Eden-Cinéma, and, finally, in an auto-fictional genre in The Lover and The North China Lover. In these works, the mother-character is described as a manic-depressive person. Jean Vallier, however, whose efforts in demystifying the claims of this notoriously unreliable writer are most welcome, does not present a single piece of evidence to suggest mental illness concerning the author's mother, Marie Donnadieu, in his extensive (I 500 pages) biography. Indeed, on the contrary, he argues that Duras has made up a great number of stories about her experiences in Indochina and presented them as the truth (Vallier, 20I0, p. 770). He presents testimonials from individuals in her entourage who call her a "grande mythomane" and a "mythomane extraordinaire" (ibid., p. 783) and who affirm that, as far as they could tell from interacting with Marie Donnadieu in the I950s, Duras's mother was not mentally disturbed (ibid., p. 832).

The same Durassian tendency to "spin a yarn" explains the reviewer's statement concerning the family's poverty and lack of prestige. In fact, Duras depicts them repeatedly as white trash in her literary work, but this claim is also contradicted by Vallier (2010, pp. 354 and 357) in his well-documented biography.

I will now present one last example to illustrate this tendency of established critics to, rather naively, take Marguerite Duras's assertions at face value. The context is the following: the review was written by Clara Törnvall (a cultural journalist, presenter of cultural news on Swedish national television) and was published in the prestigious and highbrow news-magazine Fokus in 2007. Here, Törnvall presents Duras's version of one very central biographical detail without questioning it at all - a classic example of the phenomenon discussed in this section:

The mother decides not to return to France. She dreams naively of becoming rich and buys an allotment of land in Cambodia. But she is cheated; she does not know the first thing about farming and does not understand that in order to get a fertile piece of land, she has to bribe the civil servants working in the colonial administration (Törnvall, 2007). ${ }^{18}$

I8 My translation. The original review reads: "Modern beslutar sig för att inte återvända till Frankrike. Hon när naiva drömmar om att bli rik och 
It should be noted that the quotation above does not discuss Duras's literary oeuvre, but rather her biography - and that is precisely why the text turns out to be problematic. Duras has in all her Indochinese works, as well as in numerous interviews, claimed that her mother was cheated by the French colonial agents when buying a concession of land in Cambodia. In order to get a decent parcel, Duras argues, one had to bribe the civil servants working in the colonial bureaucracy. But Duras's mother was not aware of the rules of the game in this corrupt colonial society, so she ended up ruined, owner of a practically worthless piece of land that was regularly flooded by the waters of the Pacific Ocean. The theme is recurrent in Duras's works, and this experience is often presented as the very basis for her severe condemnation of France's colonial project. ${ }^{19}$ But the information given time and again by Duras in her (auto)fictional literary oeuvre and in various paratexts (published interviews, transcribed oral conversations, etc.) was falsified by her biographer, Jean Vallier, who took the trouble to consult official French and Cambodian documentation dating from the French colonial era. These documents show that Marie Donnadieu bought the concession from a Vietnamese individual by the name of Trang Long Phung (Vallier, 2010, pp. 317-3I9). So, if Duras's mother was indeed deceived by someone somewhere along the line with regard to this transaction, it was not by the French colonial administration. But this fact contradicts the more romanticized myth promoted by Duras herself, and it is never mentioned in the reviews of my corpus.

In conclusion, the established literary criticism examined in this study represents a dominating discourse. The reviews are written by rather well-known Swedish cultural journalists and published in prestigious publications. The texts consist of numerous declarative sentences expressed in an authoritative style. They can be classified as examples of a pseudo-objective discourse, because they often present subjective opinions disguised as cold facts.

köper en jordlott i Kambodja. Men hon blir lurad, är okunnig om jordbruk och förstår inte att hon måste muta kolonialförvaltningens tjänstemän för att de ska tilldela henne bördig mark" (Törnvall, 2007).

19 See, for instance, Un Barrage contre le Pacifique (1950, p. 25) and L'Eden Cinéma (1977, p. 2I), where Duras uses the expression "le grand vampirisme colonial" to designate the perfidy of the colonial system. 
Despite the authoritative tone used, the reviews are not devoid of error. The initiated reader may also find that the texts are characterized by a certain naivety, since they tend to confound fiction, myth and reality.

\section{Reviews Published in the Blogosphere - An Alternative Literary Criticism}

I will now present some representative examples of alternative literary criticism published on the Internet. The first example is a review of the Durassian essay Att skriva (English title: Writing):

Happy Saint Lucy's Day! Today I'm off to the Swedish church to see the procession of Saint Lucy. Very excited about that. But in the meantime I will show you what I've been reading lately:

First we have Writing by Marguerite Duras, which I got from Yrsa for my b'day. The book is partly about writing and creating, but it is also full of philosophical thoughts and anecdotes from her life. I don't understand everything in this book, but that's what I like. Because reading is also about being conveyed an emotion. It really is (Wiström, 20I 5 ). ${ }^{20}$

In her definition of critical discourse analysis, Wodak (I997, p. 6) argues that a discourse is determined by the "situation, institution and social structure" that surround it; therefore, "discourse is socially constituted, as well as socially conditioned". We can see an example of this phenomenon, I believe, in the blogpost given above. The text is representative of the vast majority of alternative reviews in my corpus, insomuch as its distinguishing feature is a prose very much centered on the perspective of the individual reviewer - including five "jag" (I) and one "min" (my) referring to the blogger herself in the short excerpt. This detail, of

${ }^{20}$ My translation. The original blogpost reads as follows: "Glad Lucia! Idag ska jag till svenska kyrkan för att se luciatåget. Mycket peppad på detta. Men under tiden kan ni få se vad jag har läst på sistone: Först ut har vi Att Skriva av Marguerite Duras, som jag fick av Yrsa på min fölsis. Boken handlar delvis om skrivandet och skapandet, men den är också fylld av filosofiska tankar och anekdoter från hennes liv. Jag förstår inte allt i den här boken, men det är också det jag tycker om. För läsning är så mycket mer än att få konkreta svar. Läsning handlar också om att bli förmedlad en känsla. Ju" (Wiström, 20I 5 ). 
course, distinguishes it quite clearly from the established criticism discussed above - which, as we have seen, is characterized by the neutral tone of traditional cultural journalism. It is a text that reveals glimpses of the reviewer's personal life ("Happy Saint Lucy's Day! Today I'm off to the Swedish church to see the procession of Saint Lucy. Very excited about that" [my translation]). We can also note that colloquial speech is used, the term "fölsis" being a slang abbreviation for "födelsedag" (birthday).

The second excerpt presented here is a review of En fördämning mot Stilla Havet (The Sea Wall) written by the pseudonym "Eli":

Many people have probably, like me, put up a wall against the outside world at one time or many times. A couple of years ago I erected real ramparts around myself, I still do sometimes when other people seem too annoying and I don't have the strength to deal with the pictures of reality.

[Descriptive text, résumé of the plot.]

I have only ever read The Lover by Duras, but there is no doubt that her fantastic language is present in this book as well, and I think I will love Duras's other books too (Eli, 20I4). ${ }^{21}$

Here we have another example of the bloggers' often egocentric point of view. The review is based on the individual's personal situation, overtly transmitting his or her own perception of the world. The reviewer speaks of his or her problematic relationship with other people. ${ }^{22}$ The frequency of first-person pronouns in this excerpt is as high as in the first example: 5 "jag" (I), and I "mig själv" (myself), all referring to the blogger himself (or herself). The review shows how important it is that the literary text be relevant to the reader's own life. This aspect is also well-known in academic reader-response research. See, for instance, Sarland

2г My translation. The original text: "Många är vi nog som någon gång, eller många, haft en fördämning mot omvärlden. För några år sedan byggde jag upp verkliga vallar omkring mig själv, ibland gör jag det fortfarande när andra människor känns alltför påträngande och jag inte riktigt orkar med bilderna av verkligheten. [...] Jag har tidigare bara läst Älskaren av Duras men det är ingen tvekan om att hennes fantastiska språk finns även i den här boken och jag tror jag kommer älska även Duras andra böcker” (Eli, 20I4).

${ }_{22}$ The sex of the individual is not clear in this case, because the chosen alias (Eli) may refer to a man as well as a woman. 
( 1991, pp. 79-90) who stresses the importance of "finding yourself in the text", especially for young and inexperienced readers.

In this case, the literary work is said to reflect the reviewer's own experiences. The blogger draws a parallel between the sea wall in the Durassian novel and the abstract and intangible walls erected by the reviewer to protect himself (herself) from the outside world.

Sometimes, a blogger may identify herself with Duras on a personal level, drawing parallels between their respective lives and their personalities - as can be seen in this review of Att skriva (Writing):

Writing is a book used in a creative-writing course that I am taking at the moment. I may have quoted Lagercrantz more often, but I recognize myself most in Duras. Not in the anguish and the despair, no: writing is, for me, a joy and intoxication. But I recognize myself in not knowing how not to write, that writing is a need. This quotation from page $\mathrm{I} 3$ illustrates a way in which Duras and I resemble one another:

Writing was the only thing that inhabited my life and made it magical. I wrote. The writing has never abandoned me.

Duras was probably not an easy person to live with. Nor am I. We both share the need to be alone, but I don't need to be physically isolated. Peacefulness and people who understand my need to write, that's the sort of loneliness amongst people I need. A distance between me and my fellow being (Nilsson, 201 5 ). ${ }^{23}$

In this quotation, the navel-gazing perspective is perhaps even more salient than in the previous examples, with Io "jag" (I), 4

${ }_{23}$ My translation. The original blogpost reads as follows: "Att skriva är kurslitteratur i en kurs i kreativt skrivande som jag läser just nu. Jag må ha citerat Lagercrantz mest, men det är Duras jag känner igen mig mest i. Inte i våndan och förtvivlan, nej: skrivandet för mig är en glädje och ett rus. Men jag känner igen mig i att jag inte vet hur man låter bli att skriva, att skrivandet är ett behov. Detta citat från sidan I 3 illustrerar på ett sätt som jag och Duras är lika på: Att skriva var det enda som befolkade mitt liv och gjorde det magiskt. Jag skrev. Skrivandet har aldrig övergett mig. Duras var nog inte en lätt person att leva med. Jag är inte heller det. Behovet att vara ensamma har vi båda, men jag behöver inte vara fysiskt ensam. Ostördhet och människor som förstår att jag behöver skriva, den typen av ensamhet bland folk behöver jag. Ett avstånd mellan mig och min medmänniska” (Nilsson, 2015). 
"mig" (me), and I "min" (my), all referring to the blogger herself in the above extract. The reviewer reveals that she has read Writing as a course assignment. She may have quoted another author (Lagercrantz) more often, she says, but she "recognize[s] [her]self most in Duras", and she finds a quotation that illustrates the way in which she and Duras resemble each other. She draws another parallel between their personalities when arguing that "Duras was probably not an easy person to live with. Nor am I" [my translation]. Then she proceeds to explain in what way she believes they are alike.

One might think that this kind of extremely self-centered review would be of interest only to the individual blogger. However, quite the opposite is true. These prosumers have become commercially important agents due to their sometimes large number of followers, readers who rely on their literary judgment and who are, one gathers, big consumers of literature ( $c f$. Steiner, 20 I 2 , p. 6I). Therefore, the subjective opinions expressed in these reviews have a commercial value. The reviews are important to publishing houses and to booksellers because they serve as advertisements, regardless of whether the opinion expressed be positive or negative. ${ }^{24}$ It is, in fact, most often positive. An individual who expresses his or her opinions on a personal blog is more likely to write about literature that he or she likes than about books that he or she finds uninteresting or boring. When the blogger quoted above gives Duras's essay five stars out of five and concludes her review with the euphoric phrase "One thing's for sure: I've got to get my own copy of Writing!" [my translation], it is obviously her personal and spontaneous opinion. And from her readers' point of view, this kind of praise will always be more relevant and

${ }^{24}$ For the reader's (and potential buyer's) convenience, the reviews are sometimes linked to other reviews of the same literary work, and to online bookstores, where it can be purchased. See the following example regarding a review of The Lover: "Others who have written about the novel are Bokstugan and TinaO. You'll find it, for instance, at Adlibris and Bokus" [my translation]. (http://www.bokblomma.com/I I 26I /duras-marguerite/alskaren). The words underlined in the quotation represent a byperlink, which means that when the reader clicks on them, he or she is automatically redirected to these websites. 
interesting than a "normal" advertisement, or even a review emanating from the sphere of established criticism.

A prosumer may also assume the role of a promotor of the literature discussed in direct interaction with the readers - as illustrated in this short dialogue, which follows the review of The Sea Wall discussed above:

[Reader: comment] It seems really interesting. I have considered reading something by Duras for a long time, but I have never got around to doing it.

[Blogger: reply] I'm sure you'd like her!'55

When the reader of the blog states that she has never read a work written by Duras, the blogger (Eli) replies "I'm sure you'd like her!", which looks very much like an incitement to read (and maybe even to purchase) a work by the author.

Manifestly, the bloggers in my corpus have no problem revealing their sometimes limited knowledge, understanding and familiarity with the subject matter, i.e., Duras's literary work and the context surrounding it:

I don't understand everything in this book, but that's what I like (Wiström, 20I 5 ). ${ }^{26}$

I have only ever read The Lover by Duras, but there is no doubt that her fantastic language is present in this book as well, and I think I will love Duras's other books too (Eli, 20I4). ${ }^{27}$

[I] have just finished Marguerite Duras's Ten-Thirty on a Summer Night from I960, a short and exquisite novel. It's the first book by Duras that I have read, but I immediately felt the urge to read more (Flynner, 20I4). ${ }^{28}$

${ }_{25}$ My translation. The original dialogue reads: "[Reader: comment] Den verkar helt klart intressant. Jag har länge tänkt att läsa något av Duras, men det har aldrig blivit av. [Blogger: reply] Jag tror absolut du skulle gilla henne!" http://elilaserochskriver.se/fordamningar-som-brister/

26 Wiström, 201 5, my translation.

27 Eli, 20I4, my translation.

${ }^{28}$ Flynner, 20I4, my translation. The original blogpost reads as follows: "Nyss läst ut Marguerite Duras Halv elva en sommarkväll från I960, en kort och underbar roman. Det är den första Duras-boken jag läst, men jag får omedelbart lust att läsa fler.” 
There are many classics written by women out there, and there are many that I haven't read. I got a tip concerning Marguerite Duras and chose her book The Lover (Lager, 20I4). ${ }^{29}$

The Lover is about a young woman who is raised in the French colony "Indochina" (nowadays Vietnam, Google has informed me) with her impoverished mother and her brothers (Linnea, 20I4).30

In the examples quoted here, we can see how the reviewers reveal how they had no - or very limited - previous experience of Duras's oeuvre before reading the novel that they have chosen to present on their blog. One blogger (Wiström) is not afraid to admit that there are aspects of the literary work that she does not fully comprehend, and another individual (Linnea) openly admits to having to use the search engine Google to find the meaning of the word Indochina. This very frank and somewhat intimate way of approaching the subject matter seems to be a strategy used by the bloggers to create a nice and relaxed atmosphere, and to build a personal relationship with the readers. Obviously, the bloggers want to avoid a highbrow attitude, and they make it very clear that they do not intend to speak to the audience from a patronizing perspective. On the contrary, the message transmitted is that these non-established critics have no pretensions of knowing more than the implied reader of the review.

This open-hearted and down-to-earth attitude of the reviewers is a characteristic feature of the criticism found in the blogosphere. I would like to link it to one of the assumptions of this study, namely that it is an alternative discourse. Apparently, there is no fear of appearing ignorant or ill-informed in this arena, maybe because these individuals have no positions of power to defend in the field of cultural production. The people who express themselves on personal blogs on the Internet do not normally belong to the cultural elite, and therefore they do not have access to the prestigious tribunes of the traditional press. If anything, they represent

29 Lager, 20I4, my translation. The original text: "Det finns många klassiker skrivna av kvinnor därute och det är många som jag inte har läst. Jag fick tips om Marguerite Duras och valde hennes bok Älskaren.”

${ }^{30}$ Linnea, 20I4, my translation. The original text: "Älskaren handlar om en ung kvinna som växer upp i den franska kolonin "Indokina" (nuvarande Vietnam, har jag googlat mig till) med sin fattiga mor och sina bröder." 
voices speaking from the margins of the literary field. See, for instance, Van Dijk's (200I, pp. 355-356) discussion, quoted above, about how the elite tend to control the public discourse - and how ordinary people tend to be locked out of these arenas.

In the dominating discourse of the established criticism, on the other hand, there are no examples of this tendency to reveal various shortcomings. As we have seen above, this discourse is characterized by an authoritative tone and a great number of declarative sentences.

\section{Interaction on the Internet}

Generally speaking, the interaction is not very developed in my corpus, even though the Internet allows for a great deal of communication between people. In most cases, if there is any dialogue at all, the original blogpost is followed by a single question or a short comment by a reader, who then receives a reply from the blogger. Very few Internet reviews in my corpus transgress this basic structure of interaction. In fact, there is really only one clear exception to this rule: a review of the Durassian novel The North China Lover written by the literary author and publisher Bo Cavefors, and published as a "guest review" on the website Dagens bok. It is worth noticing that Cavefors distinguishes himself from the vast majority of Internet reviewers present in the corpus insomuch as he has a long career in the field of cultural production. He has accumulated a great deal of symbolic capital and is, presumably, a rather well-known figure in the eyes of the reading public. Therefore, he must without any doubt be regarded as an established voice in the literary field.

This text (Cavefors, 2007) attracted no fewer than 2I comments in the weeks following its online publication in April of 2007. The reason for this is, presumably, the reviewer's somewhat provocative presentation and argumentation. ${ }^{3 \mathrm{I}}$ In his reading of Duras's novel, he chooses to focus on two of the many themes present in the text, namely that of the main character's (a teenage girl's) sexual relationship with an adult man, and that of the incestuous bond between the young girl and her brother. Since

${ }_{31}$ The title of the review is "Duras om barnets rätt till sexualitet" ("Duras on the child's right to sexuality" [my translation]). 
Cavefors disregards other important aspects of the narrative (such as the unequal and power-based relations between colonizer and colonized, and the rather complex relationship between mother and daughter in the novel), the reader of the review can easily get a slightly biased impression of the story, especially of course if he or she has not read the novel beforehand. The reviewer expresses a very favorable opinion of the way in which Duras treats the sexual theme. "It is courageous and it is magnificent" [my translation], his conclusion reads.

Some commentators found the review provocative, and this resulted in an exchange of opinions and ideas that wildly exceeds anything else that can be found in the corpus, with regard to interaction. Here are two of the many hostile reactions:

Besides the fact that the review is poorly written, I am very disturbed by the non-arguing, blind ovation. Children and adult sexuality have nothing to do with each other. The child may well have taken the initiative; an adult should nonetheless never have sex with children. And how can it be considered as psychological profoundness and inner strength for a fifteen-year-old girl to have sex with her younger brother?? (Sanna) ${ }^{32}$

c'mon, really, the review is disgusting and stupid. a not very enviable combination. would be nice if dagens bok could proofread its reviewers (Viktor). ${ }^{33}$

Manifestly, these commentators find the review highly immoral. There is no indication that they have actually read the novel, so the moral outcry more likely concerns the review only. We can

${ }^{2}$ My translation. The original comment reads as follows: "Förutom att detta är en dåligt skriven recension blir jag väldigt illa berörd av det oargumenterande, blinda hyllandet. Barn och vuxensexualitet har ingenting med varandra att göra. Må så vara om det var barnet själv som tog initiativet, men en vuxen ska ändå aldrig ha sex med barn. Och hur kan det ses som besvis $[\mathrm{sic}]$ på mentalt djup och inre styrka att en femtonårig flicka har sex med sin lillebror??” http://dagensbok.com/2007/04/07 /marguerite-duras-alskaren-fran-norra-kina.

33 My translation. In Swedish: “alltså verkligen, recensionen är otäck och enfaldig. en mycket litet avundsvärd kombination. vore bra om dagens bok korrläste sina recensenter". http://dagensbok.com/2007/04/07/marguerite -duras-alskaren-fran-norra-kina. 
also note that the commentators make no distinction between reality and the fictional universe. They condemn the sexual relations represented in the literary text in the same way as they would, presumably, condemn similar relations conducted in the real world.

Other readers choose to stand up for the reviewer. Viktor's contribution, for instance, is met with opposition by another person (Daniel), who reads between the lines of the comment and interprets it as a call for censorship. One commentator (Daniel M, unclear if it is the same individual as "Daniel" above) says that he finds this review better than anything else published on the website Dagens bok:

Viktor; I also don't understand what you mean by proofreading, you seem to be referring to some kind of censorship (Daniel). ${ }^{34}$

The review is truly excellent. It reaches a level that dagensbok .com seldom attains, or even dares strive for (Daniel M). ${ }^{35}$

One observation can be made after examination of the corpus of this study: without the inclusion of a provocative element, as in the example discussed above, it is apparently rather difficult to create a genuine exchange of literary and aesthetic ideas on the Internet. Hence, the interactive possibilities of Web 2.0 are often underutilized by the bloggers and their readers. ${ }^{36}$

\section{Conclusions}

The alternative criticism published on the Internet is a rather new phenomenon, and one that has enriched the literary debate insomuch as it allows ordinary readers - i.e., individuals who do not occupy positions of power in the field of cultural production - to discuss literary works and express their point of view publicly.

${ }_{34}$ My translation. In Swedish: "Viktor; Jag förstår inte heller vad du menar med korrläsning, du verkar vara ute efter någonslags censur”. http:// dagensbok.com/2007/04/o7/marguerite-duras-alskaren-fran-norra-kina.

35 My translation. In Swedish: "Recensionen är verkligen storartad. Den når verkligen nivåer som dagensbok.com sällan når, eller ens vågar sträva efter”. http://dagensbok.com/2007/04/o7/marguerite-duras-alskaren-fran-norra -kina.

${ }^{36}$ Comparable results may also be found in previous studies: see, for instance, Aronsson (201 2, pp. 77-88) and Söderlund (2012, p. 197). 
It may be noted that there is a majority of women reviewers in the alternative literary criticism examined here - but the same is true, in fact, of the established criticism published in the Swedish press. ${ }^{37}$ Thus, judging from the corpus of this particular study, the "prescriptions of silence" imposed on women, and identified by Sheldon ( 1997, p. 228), seem to have disappeared from both arenas in the early twenty-first century (that is, in Sweden - the situation may be quite different in another cultural context). One should also remain careful when interpreting these results; Marguerite Duras is a female, and some would also say a feminist, writer. Therefore, her oeuvre is likely to appeal to women readers more than might the average novel on the market. It remains to be seen if women reviewers would outnumber critics of the masculine gender also in a reader-response study focusing on a hardboiled and macho male literary work.

The questions formulated in the introduction of the study read as follows: What are the main characteristics of the dominating discourse of the established criticism, and what are the main characteristics of the alternative discourse in the blogosphere? We can now conclude that the alternative criticism is a form of literary commentary that, in many ways, differs from the established criticism. In fact, my corpus shows that the bloggers do not try to duplicate the established critics by imitating the reviews published in the traditional press. On the contrary, they often write openly subjective reviews - private opinions expressed in a, sometimes, intimate tone. The bloggers do not seem afraid to reveal their lack of knowledge or experience - and by playing the "amateur card", they aim, presumably, to create a friendly and non-prestigious atmosphere in their respective literary blogs. On the other hand, the interaction in these blogs is rather underdeveloped - the only exception being a provocative review that has attracted many comments. This example (Bo Cavefors's reading of The North China Lover) is the only one in the corpus that contrasts with the warm and good-natured ambience of mutual agreement reigning

37 See Aronsson (2016, pp. 7-9). As a matter of fact, the same thing can be said about the academic research focusing on the works of Marguerite Duras that has been quoted in the study - it is also dominated by female scholars. 
in this part of the blogosphere. This reviewer has an impressive $\mathrm{CV}$ that sets him apart from the other online critics present in the corpus. Quite clearly, his long career in the literary field makes him an established critic - a fact that distinguishes him from the other online reviewers who, if anything, represent alternative voices, or voices speaking "from the margins" of the literary field.

The results show that the two types of reviews examined here (established and alternative criticism) are characterized by very different discourses. Hence, the material analyzed in this study cannot be said to illustrate the convergence culture described by Jenkins (2006). The dominating discourse of the established critics is characterized by an authoritative style and many declarative sentences, even if the reviews of Marguerite Duras's oeuvre are by no means devoid of errors - as has been shown above. I have labelled this discourse pseudo-objective, because the neutral journalistic prose employed in the reviews - where the writer remains "invisible" - often implies that subjective opinions are disguised as cold facts. In the material gathered for this study, the alternative discourse of the bloggers appears as the exact opposite. These individuals make a point of being openly subjective, frequently writing their reviews from a navel-gazing perspective. I have called these actors prosumers, because they combine the role of the consumer with that of the producer. The rise of these prosumers in the field of literary response illustrates the participatory culture highlighted by, for instance, Jenkins, Ito and Boyd (201 5 ).

\section{References}

Ahlstedt, E. (2003). Le "Cycle du Barrage» dans l'ouvre de Marguerite Duras. Göteborg: Acta Universitatis Gothoburgensis (Romanica Gothoburgensia 50).

Ardelet, C. and Brial, B. (20II). "Influence des recommandations d'internautes: le rôle de la présence sociale et de l'expertise," Recherche et Applications en Marketing, 26(3), pp. 45-69, [Online]. Available at: http://ram.sagepub.com/content/26/3/45.full.pdf + html (Accessed: 07 April 2016).

Aronsson, M. (2OI2). "La réception sur Internet de Kiffe kiffe demain de Faïza Guène,” in Ahlstedt, E., Benson, K., Bladh, E., Söhrman, 
I. and Åkerström, U. (eds.) Actes du XVIIIe congrès des romanistes scandinaves / Actas del XVIII congreso de romanistas escandinavos. Göteborg: Acta Universitatis Gothoburgensis (Romanica Gothoburgensia 69), pp. 63-80.

— (2013). "Le Thème de l'étranger chez Marguerite Duras et Tayeb Salih. Quelques aperçus," in Limam-Tnani, N. (ed.) Marguerite Duras. Altérité et étrangeté ou la douleur de l'écriture et de la lecture. Rennes: Presses Universitaires de Rennes, pp. I 87-198.

- (2016). "La réception de Marguerite Duras en Suède. La critique professionnelle et non-professionnelle," Moderna språk, I Iо(2), pp. I-24, [Online]. Available at: http://ojs.ub.gu.se/ojs /index.php/modernasprak/article/view/37I2/3079 (Accessed: 30 July 20I7).

Beckman, Å. (20I2). “Marguerite Duras: 'En fördämning mot Stilla havet'," Dagens Nyheter, 25 June [Online]. Available at: http:// www.dn.se/dnbok/bokrecensioner/marguerite-duras-en-ford amning-mot-stilla-havet/ (Accessed: ०3 March 20I6).

Bouthors-Paillart, C. (2002). Duras la métisse. Métissage fantasmatique et linguistique dans l'œuvre de Marguerite Duras. Genève: Droz.

Carlsson, S. (2010). Skrivarbok. Om konsten att skriva prosa, poesi och journalistik. Västerås: Faun.

Cassirer, P. (2003). Stil, stilistik \& stilanalys. Stockholm: Natur och Kultur.

Cavefors, B. (2007). “Duras om barnets rätt till sexualitet,” Dagens Bok, 07 April [Online]. Available at: http://dagensbok.com/2007/04/07 /marguerite-duras-alskaren-fran-norra-kina/ (Accessed: 03 March 20I6).

Chalonge, F. de (20I4). “Dans l'Orient de Marguerite Duras, que sont les Orientaux devenus?," in Chalonge, F. de, Mével, Y. \& Ueda, A. (eds.) Orient(s) de Marguerite Duras. Amsterdam and New York: Rodopi, pp. 29-42.

Duras, M. (1950). Un Barrage contre le Pacifique. Paris: Gallimard.

— (I977). L'Éden Cinéma. Paris: Gallimard. 
Duras, M. and Porte, M. (I977). Les Lieux de Marguerite Duras. Paris: Éditions de Minuit.

Eli (20I4). "Fördämningar som brister," Eli läser och skriver, 25 May [Online]. Available at: http://elilaserochskriver.se/fordamningar -som-brister/ (Accessed: 03 March 2016).

Findahl, O. (2013). Svenskarna och internet 20I3. Stockholm: Stiftelsen för internetinfrastruktur (.se internetstatistik) [Online]. Available at: https://www.iis.se/docs/SOI20I3.pdf (Accessed: I2 August 20I7).

Flynner, A. (20I4). "Marguerite Duras - Halv elva en sommarkväll," annikaflynner.blogg, I4 July [Online]. Available at: http://annikaf lynner.blogg.se/20 I 4/july/marguerite-duras-halv-elva-en-somm arkvall-2.html (Accessed: 03 March 2016).

Högström, J. (2015). “På andra sidan misären," Sydsvenska Dagbladet, I6 April [Online]. Available at: http://www.sydsven skan.se/kultur--nojen/bocker/bokrecensioner/pa-andra-sidan -misaren/ (Accessed: 03 March 2016).

Jenkins, H. (2006). Convergence Culture. Where Old and New Media Collide. New York and London: New York University Press.

Jenkins, H., Ito, M. and Boyd, D. (2015). Participatory Culture in a Networked Era. Cambridge: Polity.

Kåreland, L. (20 I4). “Marguerite Duras,” Dixikon, 23 July [Online]. Available at: http://www.dixikon.se/marguerite-duras/ (Accessed: o3 March 2016).

Lager, H. (20I4). "Recension: Duras, Marguerite; Älskaren; I984," Feministbiblioteket, 28 January [Online]. Available at: http:// feministbiblioteket.se/recension-duras-marguerite-alskaren-I984/ (Accessed: 03 March 2016).

Linnea (2014). “Älskaren,” Bokblomma, 24 January [Online]. Available at: http:/www.bokblomma.com/I I 26I/duras-marguerite/alskaren (Accessed: 03 March 2016).

Möijer, K. (I989). Svensk språkstil. Stil \&̊ stilanalys. Solna: Ekelunds. Nilsson, C.R.M. (20I5). "Att skriva av Marguerite Duras," Lacrimamens, I 5 May [Online]. Available at: http://lacrimamens .com/blog/att-skriva.html (Accessed: 03 March 2016). 
Pagès-Pindon, J. (20I2). Marguerite Duras. L'écriture illimitée. Paris: Ellipses.

Reid, M. (20I I). "Introduction," in Reid, M. (ed.) Les femmes dans la critique et l'histoire littéraire. Paris: Honoré Champion, pp. 7-9.

Ritzer, G., Dean, P. and Jurgenson, N. (2OI2). "The Coming of Age of the Prosumer," American Behavioral Scientist, 56(4), pp. 379-398, [Online]. Available at: http://journals.sagepub.com/doi/pdf/IO.I I 77 /00027642II429368 (Accessed: I2 August 2017).

Sarland, C. (I99I). Young People Reading. Culture and Response. Milton Keynes: Open University Press.

Schiffrin, D., Tannen, D. and Hamilton H. (200I). "Introduction," in Schiffrin, D., Tannen, D. and Hamilton H. (eds.) The Handbook of Discourse Analysis. Malden, Oxford and Victoria: Blackwell, pp. I-IO.

Sem-Sandberg, S. (2007). "Marguerite Duras urtexter ut ur skåpet," Svenska Dagbladet, I I October [Online]. Available at: http:// www.svd.se/marguerite-duras-urtexter-ut-ur-skapet (Accessed: 03 March 20I6).

Sheldon, A. (1997). "Talking Power: Girls, Gender Enculturation and Discourse," in Wodak, R. (ed.) Gender and Discourse. London, Thousand Oaks and New Delhi: Sage, pp. 225-244.

Showalter, E. (I98I). "Feminist Criticism in the Wilderness," Critical Inquiry, 8(2), pp. I79-205, [Online]. Available at: https://www .jstor.org/stable/pdf/I 343 I 59.pdf? refreqid=excelsior $\% 3 \mathrm{~A} 8 \mathrm{dd} 4 \mathrm{db}$ 453 f540a2ei I 269508cd2e7234 (Accessed: I 2 August 20I7).

Steiner, A. (2012). "Digital litteraturkritik,” in Lenemark, C. (ed.) Litteraturens nätverk: berättande på Internet. Lund: Studentlitteratur, pp. 5 I-63.

Söderlund, P. (20I2). "Med livet som insats. Om bokprat på internet," in Carlsson, U. and Johannisson, J (eds.) Läsarnas marknad, marknadens läsare. En forskningsantologi. Stockholm: Fritze (Statens offentliga utredningar, SOU 201 2:IO), pp. I93-206.

Törnvall, C. (2007). “Marguerite Duras - rebellen från Saigon,” Fokus, I9 October [Online]. Available at: http://www.fokus.se/2007/Io /marguerite-duras-rebellen-fran-saigon/ (Accessed: 03 March 20I6). 
Van Dijk, T. (200I). Critical Discourse Analysis, in Schiffrin, D., Tannen, D. and Hamilton H. (eds.) The Handbook of Discourse Analysis. Malden, Oxford and Victoria: Blackwell, pp. 352-37I.

Van Reis, M. (20I4). “Marguerite Duras I Att skriva,” Göteborgs-Posten, 23 October [Online]. Available at: http://www.gp.se/kulturnoje /recensioner/bocker/I.2525776-marguerite-duras-att-skriva (Accessed: 03 March 2016).

Wiström, F. (20 I 5). “Marguerite Duras,” Metromode, I3 December [Online]. Available at: http://flora.metromode.se/tag/marguerite -duras/ (Accessed: 03 March 2016).

Wodak, R. (I997). "Introduction: Some Important Issues in the Research of Gender and Discourse," in Wodak, R. (ed.) Gender and Discourse. London, Thousand Oaks and New Delhi: Sage, pp. I-20. 